\title{
THE COGNITIVIST APPROACH TO THE DEVELOPMENT OF FUNCTIONAL THINKING OF JUNIOR ELEMENTARY SCHOOL STUDENTS
}

\begin{abstract}
The paper deals with the cognitivist approach to the development of functional thinking from the period of preschool and early school age. Some recent scientific results on the capacity of child's brain undoubtedly indicate the fact that the experience that children receive on a daily basis, the way they receive and respond to the outside impressions and the stimuli to which they react shape their brain and influence the development of their general personality. A continuous fight for dominance takes place among the brain neurons, the result of which is creation the new connections between active neurons and new brain controls. The principal intention of the author is to stress the importance of a correct approach to an early-age development at the point of which the most intense development of the brain cells takes place and the paths for the total development of personality are traced out. Therefore, what happens to a child in this period is consequential for further development. The goal of this work is to stress that total cognitive development is conditioned by the development thinking at an early age. Therefore, the way we stimulate the child's functional thinking at an early pre-school age is extremely important and requires a more serious approach. Logical tasks and problem-solving situations are of special importance for the development of logical cognitive structures. The child's natural and social environments stimulate several sensory cooperative activities and increase the impact on perception, thus increasing a number of synapses. A methodological approach to activities to result in a functional thinking of children at an early age should be developed in such a way as to satisfy some higher demands than is the case with the current ones, i.e. it should stimulate children's further cognitive development.
\end{abstract}

Keywords: development, early age, functional thinking, methodological approach, stimulation. 


\title{
КОГНИТИВИСТИЧКИ ПРИСТУП \\ РАЗВОЈУ ФУНКЦИОНАЛНОГ МИШЉЕЬА КОД ДЕЦЕ НА ПРЕДШКОЛСКОМ И РАНОМ ШКОЛСКОМ УЗРАСТУ
}

\begin{abstract}
Апстракт Рад се бави сагледавањем когнитивистичког приступа у развоју
функционалног мишљења на предшколском и раном школском узрасту,
\end{abstract} до поласка у школу и млађим разредима основне школе. Новије научно мишљене о капацитету дечјег мозга недвосмислено указује на чињеницу да искуство које деца свакодневно добијају, начин на који примају и одговарају на утиске из околине, стимулачије на које реагују, обликују юихов мозак и утичу на развој личности у целини. Умозгу се одвија континуирана борба за доминацију међу неуронима чији су продукт нове везе између активних неурона и нови командни путеви. Основна идеја аутораје да укажуназначај правилног приступа уразвојуна раном узрасту, до седме године живота, где се одвија најинтензивнији развој можданих ћелија, и трасирају путеви за укупни развој личности, те је оно ито се детету догађа у том периоду од пресудне важности за даље напредовање. Циљ рада је да истакне условљеност укупног когнитивног развоја личности развојем мишљења на раном узрасту, nа је отуда начин стимулације функционалног размишљања детета на раном предиколском узрасту, како у породици, тако и у васпитно-образовној установи, изузетно значајан и захтева озбиљнији приступ. Логички задачи и проблемске ситуачије су од пресудног значаја за развој логичких структура размишљана. Окружење детета, природно и друштвено, стимулише кооперативне активности више чула и појачава утицај на перцепиију што повећава број синапси. Методички приступ активностима, које за продукт имају функционално размишљање деце раног узраста, треба развијати на нешто тежим захтевима од тренутних юихових могућности како би стимулисали њихов даљи когнитивни развој.

Кључне речи: развој, рани узраст, функционално размишљање, методички приступ, стимулација.

\section{КОГНИТИВИСТСКИЙ ПОДХОД К РАЗВИТИЮ ФУНКЦИОНАЛЬНОГО МЫШЛЕНИЯ У ДЕТЕЙ В ДОШКОЛЬНОМ И МЛАДШЕМ ШКОЛЬНОМ BOЗРACTE}

\footnotetext{
Резюме

В статье рассматривается когнитивистский подход к развитию функционального мышления в дошкольном и младшем школьном возрасте, т.е. в период до поступления в школу и в начальной школе. Современные научные взгляды о способности детского головного мозга четко указывает на то, чтоопыткоторыйдетиежедневноприобретают, способполученияиреагирования
} 
The cognitivist approach to the development of functional thinking of junior...

на впечатления из окружающей среды, стимулы на которые они реагируют, все это влияет на развитие детского головного мозга и личности в иелом. В головном мозгу ведется непрерывный бой между нейронами, при чем появляются новые связи между активными нейронами и новые пути координации и регуляции. Основная идея авторов статьи - указать на значение правильного подхода к развитию в раннем детстве, в возрасте до семи лет, когда происходит наиболее интенсивное развитие клеток головного мозга и когда определяются пути общего развития личности, таккакто, что сребенком происходит в этот период, имеет решающее значение для его дальнейшего развития. В работе подчеркивается зависимость общего когнитивного развития личности от развития мышления в раннем возрасте, и, таким образом, способ стимуляции функционального мышления ребенка в раннем дошкольном возрасте, как в семье, так и в воспитательнообразовательном учреждении, является крайне значительным и требует серьезного подхода. Логические задания и проблемные ситуации имеют решающее значение для развитя логических структур мышления. Окружающая среда ребенка, естественная и социальная, стимулируют совместную деятельность чувств и усиливают восприятия, что увеличивает число синапсов. Методический подход к деятельности, которая влияет на развитие функционального мышления у детей в раннем школьном возрасте, разрабатывается с более серьезными требованиями к возможностям детей, что стимулирует их дальнейшее когнитивное развитие.

Ключевые слова: развитие, ранний возраст, функциональное мышление, методический подход, стимуляция.

\section{Introduction}

The notion that the development of cognitive skills has its own evolution results in the question whether one can speak of functional thinking in the developing period and what is meant by the phrase functional thinking. We think that the answer to this question is affirmative, since functional thinking implies the inclusion of individuals at any developmental stage in the process of solving a problem, intensification of individual thinking skills, knowledge and experience and their connection for the purpose of the function of finding the most efficient solutions in a given situation. In order to understand the possibilities for the development of functional thinking of children at an early age it is necessary to know the characteristics of their development. Functional thinking at an early age is a part of the overall developmental process and it can be developed through carefully designed and organized activities in the process of education. We are witnessing that the world pays more and more attention to early education and all the research in this field suggests that the most intensive development of all functions of the brain happens at the age of seven. This period is characterized by the wealth of developmental potential, high level of curiosity, strong internal motivation, intensive 
memory, and noticeable sensor-motor activities. Therefore it is necessary to develop and implement practical activities with picturesque, that is iconic descriptions of things and phenomena, which are based on intuitive intelligence, and perceptual abilities (Pitt et al., 2013). It is through these activities that children put into action their mental processes and do their own reconstruction of reality perfecting their combinatorial flexibility (Kopas Vukašinović, 2006).

A large number of recent studies show that the period of early development, from birth to school age, as well as the younger school age period are crucial for the overall development of a personality. Studies confirm that a child in the period from birth to the eighth birthday is far more capable than was previously thought (Buss, 1999; Karmiloff Smith, 1991; Keller, 2007) and that children are, biologically speaking, social beings (Bruner, 1996; Buss, 1999; Ivić, 1987; Rogoff, 2003; Vigotski, 1983). If we start from the scientific facts that the genetic potential for intelligence is based on the number of "nerve cells" in the brain and the amount of connections (synapses) between neurons, the logical question is how we can influence them. Furthermore, the results of the scientific research indicate that the number of connections between neurons and the overall development of the network of synapses in the brain, and thus the development of functional thinking, can be influenced by adequate stimulatory instructional and educational interventions. Since the period of early development is extremely convenient for these influences and possible enhancement of connections between neurons, fostering adequate opportunities for play and learning proves to be of great importance. In addition, recent research suggests that logical thinking and rapid problem solving can be practiced in the educational process from the childhood's very beginning. On the other hand, if a timely and structured influence on brain functionning in the early period is absent, the development may be slower, leading to a situation in which it cannot be fully compensated later. The most significant and important in the development of a child occurs, according to Gezelle, in the early years, especially in the first few months of life. Subsequent development, taken as a whole, does not equal as much as a single act of this drama, largely filled with content (Vigotski, 1996).

So, if we start from the fact that functional thinking does not depend only on the number of developed nerve cells, but also on the number of established connections between neurons, it is necessary to stimulate the children to participate in planned activities that require logical thinking, that keep the "brain" in "shape"; the most natural and the most functional aspect of teaching and learning, inherent to childhood is, of course, the game. As knowledge itself has to be coherent, so functional thinking has to be integrally developed through cohesive content from different areas, because this is the only way it can be useful in all life situations. This suggests that the children's education is "based on cognitive and psychomotor sphere of entities (personalities) so that they could gain knowledge and skills, and to develop, i.e. form capacities" (Kadum, 2005: 45). 
The cognitivist approach to the development of functional thinking of junior...

\section{Methodological assumptions for the development of functional thinking}

We have already pointed out that the first years of life denote the period when human brain develops in the most intensive and fastest way, since it is well known that up to the eighth year a child's brain reaches $90 \%$ of the average weight (Johnson \& de Haan, 2011), so that every child can develop important life competences in the appropriate physical and social environment, since the early development substantially results from interaction with the environment (Berk \& Winsler, 1995; McCain \& Mustard, 1999; Shonkoff \& Phillips, 2000). The results of the researches suggest the need for serious consideration of providing high-quality conditions for early development and learning to ensure complete development of the individual potential of each person. There are numerous economic studies on large "cost-effectiveness" of investments in providing a favorable environment for early development and learning (Heckman, 2006; Karoly \& Bigelow, 2005) as an important argument for paying special attention to the early age development. These studies show that providing quality programs for early learning and development, along with investment in the capacity of parents to provide quality family context for learning and development, result in numerous long-term positive effects on further education, health, etc. employability.

The process of developing functional thinking is based on numerous assumptions that can be grouped into two main categories:

- Internal (subjective) assumptions and

- External (objective) assumptions.

When it comes to the internal assumptions, which have a significant influence on the development of functional thinking, we think of the assumptions form the domain of developed psycho-physical resources (skills, traits and capabilities) of the personality of a child in relation to another child (inter-individual differences) and the personality of each child (intra-individual differences). Taking into account both differences, the aim of developing functional thinking is not to minimize the difference between the acquired level of development of functional thinking between individuals, but to foster maximum development of functional thinking in each individual according to their own capabilities. Therefore, the assumptions should be sought in individual capacities, not in individual differences (Phelan, 2005). Starting from this point, educator, parent and child should be equally involved in this process.

Methodical approach to the activities aimed at the development of functional thinking of children of a certain age should be based on the real possibilities of these children, increased by the approximate level that stimulates mental development of children.

According to Piaget's theory, inclusion of new knowledge into existing knowledge system assumes the assessment of new information, so the inclusion of new knowledge creates cognitive conflict and necessitates assimilation in order to create such cognitive schemas in a coherent manner which would include both old and new knowledge (Pijaže, 1997). For children learning is motivated from within, often provoked by a cognitive 
conflict (Ćebić, 2010; Meintjes \& Grosser, 2010). In such activities, specific exercises that develop coordination of mental and physical (moving) spheres should be inevitable. If there is an error in the execution of the movement, it is labeled as "noise" which is nothing but a lack of concentration of attention. If there is agreement in the speed of thinking and action, we can say that the functionality is successfully implemented. It is possible to develop and improve functional thinking through practical activities aimed at quick resolving of problem situations that require logical thinking and action.

In educational and psychological literature, we find different classifications of individual variation regarding the difference in: the pace of learning, motivation, interests, temperament, social-emotional development, physical characteristics, introversion and extroversion, cognitive style, previously acquired knowledge, concentration, endurance, etc. Denhman and associates carried out numerous tests of socio-emotional factors in preschool children in order to predict their success at the early school age (Denham et al., 2014). The characteristics that make individuals different from others put a stamp on the individuality the teacher must take into account in order to plan activities that will contribute to the development of thinking ability, because each individual differs from others, inter alia, by means of observation, memory, thinking and ways of solving problems. Essential internal assumptions about the development of functional thinking can be classified into three categories:

- The age and developmental characteristics,

- The development of intellectual abilities,

- The type and quality of experience.

External (objective) assumptions are related to a number of factors arising from the environment, social circumstances and the context of life in general are important factors that affect them. In this regard, the external factors influencing the development of functional thinking stem from organized institutional work with children, provision of a high quality conditions for work with them and an intensive fostering of their thinking through the selection and application of appropriate activities. These assumptions are mutually supportive and conditional. Therefore, we consider them as a unified system of factors, which we take into account when thinking of enhancing the development of a functional thinking in early-age children. These assumptions are supplemented by internal assumptions because they are dependent on their dynamics. Teaching practice confirms that functional thinking, manifested through the speed and efficiency of problem solving, can be developed through an intense activity of the child in practical situations. Diatchenko and Lavrentieva put the emphasis on cognitive interest and ability to control one's own behavior as the two key moments of internal psychological preparation of the child for learning (Djačenko i Lavrentjeva, 1998). We are no longer of the opinion that genetic predisposition is crucial to the development of functional thinking, so we emphasize the importance of practice and continual exposure to the state of mental processing for the establishment of strong links between the neurons.

Since intelligence depends on the number of connections, or synapses, and since the number and distribution of them can be influenced, intelligence itself can be 
The cognitivist approach to the development of functional thinking of junior...

influenced. When the neurons connect, there is a flow of information. However, if some of these established connections are not used, they become thinner and "snap" and those that are being used - become stronger and ramify (Rajević, 2009).

So, early-age children behave like explorers, they frequently ask questions, combine and reveal, imploying all forms of intellectual activities represented in such processes.. Children will be in a position to be further thoughtfully engaged when working on solving a practical problem situation, because then they will be able to develop functional thinking and fully mobilize their own cognitive capacities. (Green et al., 2012). Therefore, the means of thinking that maintain internal relationship between subjects are highly important, because they cause the development of a specific character of opinions (Podđakov, 1992). If a child develops the ability to notice what is important, he or she will successfully transfer a learned content to similar situations. The educator should assess the complexity of the problem and provide essential help in finding ways to its solution. This is where a child's activities and creative and natural intellectual come into effect. In order to develop functional thinking in children, the use of logical puzzles in various forms is also encouraged. In the process of solving puzzle problems, the right approach is of utmost importance, along with careful consideration and multi-aspectual thinking. At this age, problems often seem to be unsolvable, whether they are given in a form of brainteasers, puzzles, riddles, etc. Children, therefore, need adequate explanations and encouragement leading to the analytical approach to the problem. It is necessary to find and extract a key part of it and think about it. Surely, in the beginning, when presented with the first examples, children will be giving up and making more mistakes. However, after just a few examples, children will get used to thinking, and they will properly address the problem and opt for an adequate approach to solve the problem. Children love short stories at this age, so the problems are reported in the form of the story problem, the teacher speaks about the morale of the story, instead of offering the solution of the problem. This is particularly why children love to participate - they ask and answer. Their cognitive curiosity should be used and, of course, all the answers (both correct and incorrect) should be taken into consideration. In this way, we encourage their activity, which we have previously mentioned as crucial to the development of functional thinking. Some authors suggest that one should keep in mind that children who grow up in an atmosphere of understanding and support use their intellectual potential without fear, which is manifested through the actions of their own research, searching, critical observation and verification of hypotheses, all of which have positive repercussions for the optimal development of individual abilities. We, therefore, recommend planning problem stories that relate to real life situations, because in this case the dual effect is being achieved - the child learns useful things that can be applied in a real life situation and they acquire the ability to use their brain functionally. This is a good approach to identify a gifted child as well, as after several examples there will be children who are more likely to frequently solve the "logical brain teasers", which is a good sign that we have a gifted child in front of us.

As an example of a story containing a logical brainteaser, we offer the following story. Story No. 1: A tall bus full of children went on a trip. However, on its way it hit 
a roadblock, it simply could not pass under a rural bridge. If it were at least three centimeters lower (the teacher vividly shows how much space it is with his the thumb and forefinger), it would pass under the bridge and continue without any problem. This way - they simply could not continue their trip. The matters were even more unfortunate, since there were no side roads, nor the flyover passage could be avoided by any means. The driver did not know what to do! Children were desperate! However, at this point, a wise farmer appeared and quickly solved the problem, so the bus slowly continued its journey (Rajević, 2010: 67).

If there are difficulties in resolving these stories, the teacher has to illustrate the problematic situation. (The solution is: The farmer told the driver to let some air from all the tires and then to safely pass under the bridge.)

When designing and planning so-called problem stories we must take into account that children at an early age do not have a developed abstract thinking, and that teachers must follow the principles of obviousness. This means that the problem must be practically demonstrated so that children would be more active in the process of their thinking and so that they could relate to different sensory-perceptual experiences. Here, observation is the basis of all activities as sensory data find their place in the memory, and turn into meaningful perceptions (Pijaže i Inhelder, 1990). This process is neither simple nor easy. A key prerequisite for a successful resolution of problem situations is to enable the child to reflect on it, using different cognitive tools to make an original mode of resolving problem situations. Therefore, it is necessary to define, i.e. to sort out the problem, because children at this developmental level usually first note what prevents them in solving it, and only then if they are able to "control" the emotion they manage to comprehensively analyze the problem. This is why the focus of attention is very important determinant in considering facts (Ognjenović, 2002). This means that after identifying problems follows the separation of the main information and their consideration in entirety. Since the problem story is a set of certain data in a particular relationship, it means that this set contains information related to the solution of the problem. Children are expected to find the solution of the problem from the given information and the relations between them.

Thus, solving the problem story helps the development of functional thinking, but to develop a particular system of defining the problem, identifying the facts and giving ideas for solving the problem situation does not automatically mean that we fully developed functional thinking in children. Namely, in the process of the development of functional thinking, apart from the formation of certain thinking "technique" (training for the application of given operations and procedures), children need to be trained in selfdiscovery and establishment of connections that enable solving new problem situations. Therefore, as pointed out by Pantić (Pantić, 1999) we should not stifle a creative atmosphere in group, but encourage eliciting ideas from children, as well as the production of new associations and empower them to ask as many as they find necessary.

The roles of parents and teachers in the development of functional thinking in early-age children are quite complex and complementary, because they are the 
The cognitivist approach to the development of functional thinking of junior...

ones who spend the most time with children during the period of their most intense development. Their work is very demanding and responsible, and must be based on continuous monitoring of the child's development. Teachers, as pointed out by Jukić (Jukić, 1997), should know the technology of learning in order to apply it in their practice. Stimulation of the development of functional thinking should be performed in all children, regardless of differences in their predispositions. Naturally, we need to make a differentiation by the level of abilities, based on the weight and complexity of content to be introduced to them. Mystery tales and questions foster development of convergent and later even divergent thinking. There is no specific scheme or formula to follow in order to develop functional thinking, but there is a clear goal of the presentation of the story with a problem situation, which eventually leads to cognitive tension in the group the product of which should be a flood of ideas. It is a psychological condition that causes anxiety in children, tension and a desire to find solutions.

If the development of functional thinking is understood broadly enough (especially if it is linked to the development of educational content), then it can be said that it is necessary to modify the practice in working with children in the family and kindergarten. NTC - Learning System (Nikola Tesla Center - Department of Mensa for gifted), written by dr. Ranko Rajović created a learning system based on the theoretical basis of neurology, neuropsychology and other sciences, in particular pedagogical ones such as Family Pedagogy, Didactics and Methodology for pre-school and primary school age. The mentioned learning system influences the theoretical knowledge and provides instructions on how to connect theory with educational practice. This is a new approach to learning, which is dominated by interaction and thinking activity of the child and its successful development. The system is very good and worked out in details, applicable in the family, preschools and in elementary-school grades (Rajević, 2010).

Stimulation of the development of functional thinking is achieved mainly with the problem-solving process of reasoning and motor activities. When solving puzzles, riddles, logic puzzles and problems, children these divergent stories test different options for which children need certain cognitive assumptions of functional thinking.

The activities that directly promote the development of functional thinking should be implemented not only in kindergarten, but also in the family. The need for such activities is based on modern concepts of a more complete development of personality. This is not a matter of a forceful, linear hastening of the development process (acceleration), but providing/enriching conditions to encourage integrated development (amplification). Early-age children should be given more attention and educators should engage them in as many activities in which they would manipulate various play materials through exchanges with peers and adults (Rossouw, 2009). By asking different types of questions, teachers and parents provoke different levels of thinking (Steel \& Temple, 2000). These are good strategies, methods and procedures for early-age children, by which they learn proper skills to establish connections and relationships between components in a problem situation, that is when they develop functional thinking abilities. Specifically, in the process of functional thinking development, beside the formation of certain 
thinking "technique" (ability to master fixed operations and procedures), children need to be enabled to discover new connections and general practices/procedures that enable solving new problem situations and acquiring new skills and knowledge. Failure to resolve problem situations is caused by the selected strategy/procedure for perceiving challenges. Kostić in his Cognitive Psychology singled out the most important factors of influence on the successful resolution of problems: functional fixity, that is concentration on a single function of the object or (in)ability to analyze a situation from another perspective, the impact of cognitive orientation, neglecting the essential elements of the problem (Kostić, 2010).

Robbie Case (Case, 1992), who points out the importance of short term memory, argues that overall children's abilities to resolve problem in playing situations are caused by their "working space" (metaphorical expression - the amount of mental energy needed to solve the problem) and short-term storage/disposal of information. Progress in solving problems through playing situations occurs with the expansion of "space" for the short-term storage of information. According Case's theory limits of this "space" are the reason for the children's inability to solve problems, while progress happens when the child is able to combine the operations previously performed separately. Along with their development, children become more skilled in performing cognitive operations, which contributes to their overall maturation, exercise and stimulation. This is confirmed by most theories dealing with cognitive development as well the one provided by Case, which states that memory increases with the development of the individual, which is the basis of all the more perfect judgment, functional thinking and problem solving (Vasta et al., 2004)

\section{Interactive activities as a factor of development the functional thinking in early-age children}

Keeping in mind the above highlighted fact that the practice of problem-solving at an early age is one of the most appropriate ways of facilitating and stimulating strong functional thinking in children, one of the most complex tasks for educators working with children at an early age is the selection of appropriate procedures and strategies for the most appropriate stimulation of the development of mental functions. Interaction among children contributes to the change of their operational behavior, which is important for the development of cognitive structures (Pere Klermon, 2004). In order to encourage the development of functional thinking abilities at that age, one has to provoke a particular interest in them. In doing so, children need to master the general approach of dealing with problem situations, instead of being introduced to some fragmentary facts and the like. Early-age children master their environment, and thus the instruments of their own development through play (Montessori, 2007). Each phase of development is marked by an "explosive activity" and varieties of playing, according to Wallon (1985). Piaget sees children's play as a part of their cognitive development and connects it with the structure of mental activity. As a multifunctional, ambiguous, 
The cognitivist approach to the development of functional thinking of junior...

non-specialized activity, playing is really associated with cognitive development (Duran, 2003). Interaction and communication have formative and constitutive purpose in the development of higher mental functions. Therefore, teacher, parent and other adults who work and live with children create opportunities where children project their cognitive curiousness in relation to the world around them, solve motor-sensory intelligence problems, enrich their speech as a means of communication, build cognitive concepts through practical-playing activities (Ivić, 2010).

Kopas Vukašinović (2006) points out that the games has exploratory character since children, through the development of appropriate and cognitively provocative content of playing, search for solutions, by eliminating mistakes and unnecessary moves. They experiment without external or internal pressures, continuously searching for new opportunities and gradually passing from pre-logical to logical thinking phase. While playing, children develop all of their abilities (perceptual-motor, intellectual, socioemotional, communicative and creative), while cognitive development is the result of a dialectical process by which a child learns through the shared experience of solving problems with others (Vigotski, 1983). Unlike Piaget, who emphasized the child's own efforts to understand the world around them, Vygotsky's cognitive development is seen as a socially mediated process that depends on the help of adults and mature children (Berk, 2008). In doing so, the child learns to connect facts into regulated mental entities and combinations, which is the integrative function of the game. During the play, the child practices different cognitive processes - perceiving, recognizing, and classifying. In this way, as pointed out by Kopas Vukašinović, the symbolic transformation of experience and development of the child comes into effect. Mirjana Duran states that symbols have a noteworthy function of representation. There is a sign and signified, that is reference and intentionality of representation. Children try to represent their experiences, ideas, and relationships using symbols (Duran, 2003). Through well-designed, exploratory game adults encourage children to mentally reconstruct the experience, to internalize, and gradually distance themselves from the immediate. Games like "Guess who?", associations games, puzzles, and role-playing games, stimulate children's creative abilities to connect and combine (Kragić i Bruno, 2009). Ivić and Davidović, basing their opinion on findings of their experimental studies, show that younger children need perceptual support and analogous substitutes for structuring a symbolic play while older children use unstructured materials and change their mental plans more often and more effectively (Duran, 2003).

The first semiotic resources in a game are, as pointed out by Vygotsky (1983), closely associated with what they denote/indicate (iconic and arbitrary means). With the development of children's thinking, we see a greater distance between the semiotic resources and the reality, that is, between the symbolic resources and denoted objects. We are talking about departing from or the autonomisation of the replacement object in the game with the progress of thought. Piaget explained that this was a deforming assimilation of objects associated with the increasing autonomy of semiotic resources and thought itself. Therefore, symbolic play reflects the level of cognitive development, 
as the basis of human thinking is the operation of symbols. Cognitive psychologists recognize different levels of intellectual functioning: elementary operations, strategies dealing with various tasks and metacognitive processes (Duran, 2003). Children take the information from the environment and transform it, integrating it into an existing cognitive schema. In doing so, they process it, according to Piaget. Bruner argues that the development of thinking can be influenced by appropriate educational incentives through play. Children adopt methods of representation of periodic patterns in their environment, during the development, at the same time developing the mechanisms of representation and integration (Horvat, 1986). Children's experience and creativity contribute to the variation of games they play. If we take into account some of the characteristics of a pre-school children such as: pronounced cognitive curiosity, expressed emotionality, unfinished internationalization of practical actions, as well as their need for active testing, combining, research, then it is clear how games can have a strong educational character and contribute to intrinsic motivation and the creation of new mental structures. Cognitive and emotional de-centration takes place in playing situations. By its nature, the game is interactive and promptly affirms action on the verbal level (Moodley, 2013). Moving to a new semiotic plan introduces children to inter-individual exchanges, and later on intra-individual developmental level. By following maturation of symbolic play, we see the gradual transformation of the singleact "like" procedures to very complex combinations of acquired signs/symbols and their integration into a unified composition. Common play involves social and cognitive skills, the ability of social interpretation, thoughtful negotiation strategies and various strategies of social behavior. Thus, the ability to exercise functional thinking can develop at a very early age.

\section{Conclusion}

Intensive development of functional thinking takes place in various conditions during continuous organic maturation of the central nervous system. Since this process is most evident at an early age, there is a special opportunity for the efficiency of organized work at the preschool age. Vast possibilities of early education, expressed through intellectual and motivational potentials, are obvious. Encouraging and motivating the child's activity also proves to be of vital importance. Functional thinking in this age group relies on sensory and emotional processes, performances and practical activities. Thanks to them functional thinking is faster, stronger and develops in a more versatile manner. It is also the basis for the development of the highest form of thought - abstract thinking. Symbols play a special role in the development of functional thinking. Thus, the major carriers of abstract thinking are speech symbols, while thoughtful recognition of connections and relationships, established in the mental system, is an integral part of the learning process.

Taking into account the importance of early learning from a cognitivist viewpoint we propose the following measures that would contribute to the improvement of operational thinking in preschool and junior elementary-school grades: 
The cognitivist approach to the development of functional thinking of junior...

- Do not ignore the fact that each stage in the child's development is equally important and provide proper access to the child at all age levels;

- Educate parents/guardians about the importance of a professional approach to the development of the child, in this case cognitive development;

- Train educators or teachers to plan and implement activities that promote the development of functional thinking of children of a given age;

- Complete and functionalize documentation that accompanies the development process at all age levels, because in this way we will create a more realistic insight into the child's individual needs and capabilities;

- Establish appropriate and effective educational strategies in working with children of preschool age and elementary school grades;

- Plan and implement the activities related to life context, make objectives and themes operational and useful from the perspective of the child,

- Establish appropriate and effective educational strategies in working with children of preschool age and elementary school grades;

- Improve the cooperative relationship between parents as educators and teachers.

\section{References}

Berk, L. (2008). Psihologija cjeloživotnog razvoja. Jastrebarsko: Naklada Slap.

Berk, L. \& Winsler, A. (1995). Scaffolding Children's Learning: Vygotsky and Early Childhood Education. Washington: National Association for the Education of Young Children.

Bruner, J. (1996). The Culture of Education. Cambridge: Harvard University Press.

Buss, D. (1999). Evolutionary Psychology. London: Allyn \& Bacon.

Case, R. (1992). The Mind's Staircase: Exploring the Conceptual Underpinnings of Children's Thought and Knowledge. New Jersey: Lawrence Erlbaum Associates.

Ćebić, M. (2010). Početno matematičko obrazovanje predškolske dece. Beograd: Učiteljski fakultet Univerziteta u Beogradu.

Denham S. A, Bassett H. H., Zinsser K. \& Wyatt T. M. (2014). How preschoolers' social-emotional learning predicts their early school success: developing theory-promoting, competencybased assessments. Infant and Child Development, Vol. 23, No. 4, 426-454.

Djačenko, O. M. i Lavrentjeva, T. V. (1998). Psihički razvoj predškolske djece. Beograd: Zavod za udžbenike i nastavna sredstva.

Duran, M. (2003). Dijete i igra. Zagreb: Naklada Slap.

Green, L., Condy, J. \& Chigona, A. (2012). Developing the language of thinking within a classroom community of inquiry: pre-service teachers' experiences. South African Journal of Education, Vol. 32, No. 3, 319-330.

Heckman, J. (2006). Skill Formation and the Economics of Investing in Disadvantaged Children. Science, Vol. 312, 1900-1902.

Horvat, L. (1986). Predškolsko vaspitanje i intelektualni razvoj. Beograd: Zavod za udžbenike i nastavna sredstva. 
Ivić, I. (1987). Čovek kao animal symbolicum. Beograd: Nolit.

Ivić, I. (2010). Vaspitanje dece ranog uzrasta. Beograd: Zavod za udžbenike.

Johnson, M. H. \& de Haan, M. (2011). Developmental Cognitive Neuroscience (3rd ed.). Oxford: Wiley Blackwell.

Jukić, S. (1997). Učenje učenja u nastavi. Novi Sad: Savez pedagoških društava Vojvodine.

Kadum, V. (2005). Učenje rješavanjem problemskih zadataka u nastavi matematike. Pula: IGSA.

Karmiloff Smith, A. (1991). Beyond modularity: Innate constraints and developmental change. The epigenesis of mind: Essays on biology and cognition. In S. Carey \& R. Gelman, Rochel (Eds.), The Epigenesis of Mind: Essays on Biology and Cognition (pp. 171-197). Hillsdale: Lawrence Erlbaum Associates.

Karoly, L. A. \& Bigelow, J. H. (2005). The Economics of Investing in Universal Preschool Education in California. Arlington: RAND.

Keller, H. (2007). Culture of Infancy. London: Lawrence Erlbaum Associates.

Kopas Vukašinović, E. (2006). Uloga igre u razvoju dece predškolskog i mlađeg školskog uzrasta. Zbornik Instituta za pedagoška istraživanja, God. 38, No 1, 174-189.

Kostić, A. (2010). Kognitivna psihologija. Beograd: Zavod za udžbenike.

Kragić, I. i Bruno, Ć. (2009). Igra - put k multidimenzioniranom mišljenju, Na tragu filozofije za djecu. Zagreb: Institut za filozofiju.

Meintjes, H. \& Grosser, M. (2010). Creative thinking in prospective teachers: the status quo and the impact of contextual factors. South African Journal of Education, Vol. 30, No. 3, 361-387.

McCain, M. N. \& Mustard, J. F. (1999). Early Years Study: Reversing the Real Brain Drain. Toronto: Ontario Children's Secretariat.

Montesori, M. (2007). Od detinjstva do adolescencije. Beograd: DN Centar.

Moodley, V. (2013). In-service teacher education: asking questions for higher order thinking in visual literacy. South African Journal of Education, Vol. 33, No. 2, 1-18.

Ognjenović, P. (2002). Psihologija opažanja. Beograd: Zavod za udžbenike.

Pantić, V. (1999). Razvoj, učenje i mera psihičkog. Beograd: Zavod za udžbenike i nastavna sredstva.

Pere Klermon, A. N. (2004). Socijalna interakcija i intelektualni razvoj. Beograd: Zavod za udžbenike.

Phelan, T. W. (2005). Sve o poremećaju pomanjkanja pažnje. Zagreb: Ostvarenje.

Pijaže, Ž. (1997). Psihologija inteligencije Belgrade: Nolit.

Pijaže, Ž. i Inhelder, B. (1990). Psihologija deteta Novi Sad: Dobra vest.

Pitt, C., Luger, R., Bullen, A., Phillips, D. \& Geiger, M. (2013). Parents as partners: Building collaborations to support the development of school readiness skills in under-resourced communities. South African Journal of Education, Vol. 33, No. 4, 1-14.

Podđakov, N. N. (1992). Praktično mišljenje kod djece. Beograd: Zavod za udžbenike i nastavna sredstva. Rajević, R. (2009). IQ deteta - briga roditelja. Novi Sad: Abeceda.

Rajević, R. (2010). NTC sistem učenja-metodički priručnikza vaspitače. Vršac: Visoka škola strukovnih studija za obrazovanje vaspitača "Mihailo Palov".

Rogoff, B. (2003). The Cultural Nature of Human Development. Oxford: Oxford University Press. 
The cognitivist approach to the development of functional thinking of junior...

Rossouw, D. (2009). Educators as researchers: Some key considerations. South African Journal of Education, Vol. 29, No. 1, 1-16.

Shonkoff, J. P. \& Phillips, D. (2000). From Neurons to Neighborhoods: The Science of Early Childhood Development. Washington: National Academy Press.

Steel, M. \& Temple, W. (2000). Čitanjem i pisanjem do kritičkog mišljenja. Beograd: Centar za interaktivnu pedagogiju.

Vasta, R., Haith, M. M. \& Miller, A. S. (2004). Dječja psihologija. Zagreb: Naklada Slap.

Vigotski, L. (1983). Mišljenje i govor. Beograd: Nolit.

Vigotski, L. (1996). Pitanja teorije i istorije psihologije. Beograd: Zavod za udžbenike i nastavna sredstva.

\section{Подаци о ауторима}

Др Веселин Мићановић је доцент на Филозофском факултету у Никшићу Универзитета Црне Горе. E-mail: vele-nk@t-com.me

Др Татјана Нововић је доцент на Филозофском факултету у Никшићу Универзитета Црне Горе. E-mail: tabo@t-com.me

Др Дијана Вучковић је доцент на Филозофском факултету у Никшићу Универзитета Црне Горе. E-mail: dijanav@ac.me

Др Нада Шакотић је доцент на Филозофском факултету у Никшићу Универзитета Црне Горе. E-mail: ramijo@t-com.me 